\title{
Quellen und Literaturverzeichnis
}

\section{Quellen}

Antonios Hagiographikos, Vita Symeon stylitae senioris: Das Leben des heiligen Symeon Stylites, bearbeitet von Hans LiETzmann. Mit einer deutschen Übersetzung der syrischen Lebensbeschreibung und der Briefe von Heinrich Hilgenfeld, Leipzig 1908.

Apophthegmata Patrum: Alphabetische Sammlung, PG 65, col. 71-440.

- M. Jugie, Un apophthegme des pères inédit sur le purgatoire, in: Mémorial Luis Petrt. Mélanges d'histoire et d'archéologie Byzanthines, Bukarest 1948, 245-253.

- Les apophtègmes des Pères, Collection Systématique, t. I-III, Introduction, texte critique, traduction et notes par J.-C. GuY (SC 387/474/498), Paris 1993, 2003 und 2005.

Artemidor von Daldis: Artemidori Daldiani, Onirocriticon Libri V, ed. R. A. Pack (BSGRT), Leipzig 1963.

Athanasios von Alexandreia, Vita Antonii: Athanase d'Alexandrie, Vie d' Antoine, Introduction, texte critique, traduction, notes et index par G. J. M. BARTELINK (SC 400), Paris 1994.

Augustinus, De genesi ad litteram: Sancti Aureli Augustini De genesi ad litteram libri duodecim, ed. I. Zycha, Wien u. a. 1894.

Barlaam und Ioasaph: Die Schriften des Johannes von Damaskos. Historia animae utilis de Barlaam et Ioasaph (spuria), Bd. VI/1: Einführung; Bd. VI/2: Text und zehn Appendices, ed. R. Volk, (Patristische Texte und Studien 60, 61), Berlin u.a. 2006-2009.

Barsanuphios und Johannes: Barsanuphe et Jean de Gaza, Correspondence, t. I-III, ed. F. Neyt, P. De Angelis-Noah, L. Regnault (SC 426, 427, 450, 451), Paris 1997-2001.

Basileios von Kaisarea, Enarratio in prophetam Isaiam, PG 30, col. 118-668.

Cassianus: Cassiani Opera, Collationes XXIIII, ed. M. Petschenig, EditioAltera supplementis aucta curante G. KREUZ (CSEL 13), Wien 2004 (Neudruck der 1. Auflage Wien 1886).

Codex Justinianus: Codex Justinianus, in Corpus juris civilis II, ed. P. Krueger, Hildesheim 1989 (Nachdruck der 1. Auflage Berlin 1954).

De SS. Pachomio et Theodoro: Paralipomena de SS. Pachomio et Theodoro (BHG 1399a), ed. Halkin, Genève 1982, 73 -98 (s. unter Vita Pachomii). Epistula Ammonis Episcopi, de SS. Pachomio et Theodoro (BHG 1397), ed. HalkIn, Genève 1932, 99-115 (s. unter Vita Pachomii).

Euagrios Pontikos, Praktike: Évagre le Pontique, Traité Pratique ou le Moine, 2 Bde, Introduction, traduction, commentaire et tables par A. et C. Guillaumont (SC 170, 171), Paris 1971.

- Gnostikos: Évagre le Pontique, Le Gnostique, éd. A. et C. Guillaumont (SC 356), Paris 1989.

- Ad Monachos: The „ad monachos“ of Evagrius Ponticus, ed. J. Driscoll (StAns 104), Rom 1991. 45-70. 
- De malignis cogitationibus: Évagre le Pontique, Sur les penśees. Édition du texte grec, introduction, traduction, notes et index de P. Géhin, A. et C. Guillaumont, (SC 438), Paris 1998.

- Capitula xxxiii. Per gradus quosdam disposita consequentiae, PG 40, col. 1264 1268.

- Capita cognoscitiva, in: J. Muyldermans (ed.), Evagriana. Extrait de la revue Le Muséon t. 44, augmenté de Nouveaux fragments grecs inédits, Paris 1931, p. 57-68 $(21-32)$.

- De octo spiritibus malititiae, PG 79, col. 1145-1164.

- De oratione, PG 79, col. 1165-1200.

- Dialogus de contemplatione: Un entretien monastique sur la contemplation, Recherches de Science Réligieuse 50 (1962), 230-241.

Euripides, Bakchen: Euripides, Bacchae, Iphigenia at Aulis [u.a.]. Edited and translated by D. Kovacs (LCL 495), Cambridge, Mass. 2002.

Eusebios von Kaisarea, Historia Ecclesiastica: Eusèbe de Césarée, Histoire ecclésiastique II, Livres V-VII. Texte grec, traduction et notes par G. BARDY (SC 41), Paris 1955.

- Vita Constantini: Eusebius Caesariensis, Werke, Band 1, Teil 1: Über das Leben des Kaisers Konstantin, ed. F. Winkelmann (GCS Eusebius 1,1), Berlin, New York ${ }^{2} 1991$.

Eustathios Makrembolites: Eustathius Macrembolites, De Hysmines et Hysminiae Amoribus Libri XI, ed. M. Marcovich (BSGRT), Leipzig 2001.

- Eustathios Makrembolites, Hysmine und Hysminias, eingeleitet, übersetzt und erläutert von K. PlePELITS (Bibliothek der griechischen Literatur 29), Stuttgart 1989.

Gregor von Nyssa, De hominis opificio, PG 44, col. 123-256.

- De vita Moysis: Grégoire de Nysse, La vie de Moïse ou traité de la perfection en matière de vertu. Introduction, texte critique et traduction par J. DANIÉLOU (SC 1), Paris ${ }^{3} 2007$.

- Vita Macrinae: Grégoire de Nysse, La Vie de Sainte Macrine. Introduction, texte critique, traduction, notes et index par P. Maraval (SC 178), Paris 1971.

Heraklit, Fragmenta: Héraclite d'Éphèse, Les vestiges. 3. Les fragments du livre d'Héraclite, B. Les textes pertinents. Extraits des sources (II.A et II.B), établis, traduits et annotés par S. Mouraviev, Sankt Augustin 2006.

Herodot: Hérodote, Histoires, livre I, Clio. Texte établi et traduit par. Ph.-E. Legrand, Paris ${ }^{5} 1970$.

Hesiod: Hesiod, Theogony, ed. M. L. West, Oxford 1966, 111-149.

Historia Monachorum in Aegypto: Historia Monachorum in Aegypto, ed. P. FestUGIÈRE, Bruxelles 1961.

Hippokrates: Oeuvres complètes d'Hippocrate: traduction nouvelle avec le texte grec en regard, accompagnées d'une introduction (...) et de notes philologiques par É. LitTRÉ, vol. VII, Paris 1851.

- De morbo sacro: Ippocrate, La malattia sacra, a cura di A. Roselli, con testo a fronte, Venezia 1996.

Hippolyt von Rom, Traditio Apostolica: Hippolyte de Rome, La tradition apostolique d'après les anciennes versions. Introduction, traduction et notes par B. Botte (SC 11), Paris ${ }^{2} 1968$.

Homer, Odyssee: Homer, Odysse. Griechisch und Deutsch. Übertragen von A. WeIHer, mit Urtext, Anhang und Registern, Einführung von A. Heubeck, Zürich ${ }^{10} 1994$. 
Ioannes Chrysostomos, Commentarius in Acta Apostolorum, PG 60, col. 13-390.

Ioannes Klimakos, Scala Paradisi, PG 88, col. 632-1209.

Ioannes Moschos, Pratum Spirituale, PG 87.3, col. 2851-3112.

Kallinikos, Vita Hypatii: Callinicios, Vie de Hypatios, ed. G. J. M. Bartelink (SC 177), Paris 1971.

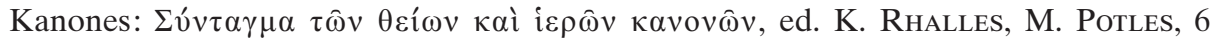
Bde., Athen 1852-1890.

- G. D. MANSI, Sacrorum conciliorum nova et amplissima collectio, Florenz u.a., 1757-1798.

Kyrillos von Skythopolis: Kyrill von Skythopolis, ed. E. SchwarTz (TU 49, 2), Leipzig 1939.

Leges: Corpus Iuris Civilis, Bd.2, Codex Iustinianus. Regognovit et retractavit P. Krueger, Dublin 1967.

- Basilika: Basilicorum Libri LX, Series a volumen VIII, textus libri LX, ediderunt H. J. Scheltema u. a., Groningen 1988.

Leon Diakonos, Historia: Leonis Diaconi Caloënsis Historiae Libri Decem et Liber de Velitatione Bellica Nicephori Augusti, e recensione Benedictii HAsII, addita eiusdem versione atque annotationibus ab ipso recognitis, Bonn 1828, 1-178.

Leontios von Neapolis, Vita Symeonis Stulti, Vita Johannis Aeemosynarii: Léontios de Néapolis, Vie de Syméon le fou et vie de Jean de Chypre, 2 Bde, ed. A. J. FestUGIÈRE et L. RYdÉn (Bibliothèque archéologique et historique 90), Paris 1974.

Markos Diakonos, Vita Porphyrii: Marc le Diacre, vie de Porphyre, ed. H. GréGoIre et M. A. Kruger (Collection Byzantine), Paris 1930.

Miracula S. Artemii: A. Papadopoulos - Kerameus (ed.), Varia graeca sacra, St. Petersburg 1909 (repr. Leipzig 1975), 1-75.

Origenes, Contra Celsum: Origène, Contre Celse, t. 4 (livres VII et VIII), Introduction, texte critique, traduction et notes par M. Borret (SC 150), Paris 1969.

Pachomios, Praecepta: H. BACHT (ed.), Das Vermächtnis des Ursprungs. Studien zum frühen Mönchtum, Bd. 2: Pachomius - Der Mann und sein Werk, Würzburg 1983, $82-225$.

Palladios, Historia Lausiaca: Palladius, The Lausiac History of Palladius. A critical discussion together with notes on early Egyptian monasticism, ed. C. ButLER (Texts and studies 6, 1.2), Hildesheim 1967.

Passio Perpetuae: The passion of S. Perpetua: together with an appendix containing the original Latin text of the Scillitan martyrdom, newly ed. from the mss. with an introduction and notes by J. A. Robinson (Texts and Studies. Contributions to Biblical and Patristic Literature 1.2), Cambridge 1891, 61-95 (repr. Nendeln/ Liechtenstein 1967).

Philon von Alexandreia: Philonis Alexandrini opera quae supersunt, Bde. III, IV und V, ed. P. Wendland, L. Cohn, Berlin 1896 (repr. 1962) und 1902 (repr. 1962).

Philostratos, Vita Apollonii: Philostratus, The Live of Apollonius of Tyana, 2 Bde, with an Engl. translation, ed. F. C. Conybeare (LCL 34), Cambridge u.a. 1912.

Platon, Phaidros: Platon, Werke in acht Bänden, griechisch und deutsch, Bd. 5: Phaidros [u.a.], bearb. von D. KuRz, Darmstadt 1983.

Plotin, Enneaden: Plotini opera, 2 Bde., ed. P. Henry and H.-R. Schwyzer, Leiden u. a. 1951 u. 1959.

Prokopios von Kaisarea, Anekdota: Geheimgeschichte des Kaiserhofs von Byzanz, griechisch-deutsch, ed. O. VEH (Tusculum-Bücherei), Düsseldorf u.a. 2005.

Prokopios von Gaza, Comentarii in Genesim, PG 87,1, col. 129-178.

- Comentarii in Isaïam, PG 87,2, col. 1801-2718. 
Pseudo-Dionysius Aeropagita, De Ecclesiastica Hierarchia: Corpus Dionysacum II: Pseudo-Dionysius Aeropagita, De Coelesti Hierarchia - De Ecclesiastica Hierarchia - De Mystica Theologia - Epistulae, ed. G. HeIL, A. M. RitTer (Patristische Texte und Studien 36), Berlin, New York 1991.

Sophronios von Jerusalem, Miracula der Heiligen Kyrhos und Johannes: Los thaumata de Sofroni: contributión al estudio de la incubatio Christiana por N. Fernandes MARCos, Madrid 1975.

Sozomenos, Historia Ecclesiastica: Sozomène, Histoire Ecclésiastique, 4 bde. Texte grec de l' édition J. Bidez, Introduction par B. Grillet et G. C. Hansen (SC 306, 418, 495, 516), Paris 1983-2008.

Synesios von Kyrene: Sinesio di Cirene, I sogni. Introduzione, traduzione e commento di D. Susanetri (Studi e commenti 10), Bari 1992.

Tertullian, De Anima: Tertulliani, De anima, ed. with introduction and commentary by J. H. Waszink, in: Tertullianus, Opera, Pars II, Opera Montanistica, Turnholt 1954.

Theodoret von Kyrrhos, Philotheos Historia: Théodoret de Cyr, Histoire des Moines de Syrie, t. I-II, Introduction, texte critique, traduction, notes et index par P. CANIVET, A. Leroy-Molinghen (SC 234, 257), Paris 1977 und 1979.

- Historia Ecclesiastica: Theodoret, Kirchengeschichte, ed. L. Parmentier, Dritte, durchgesehene Auflage von G. Ch. Hansen, Berlin 1998.

Theophanes Confessor: Theophanis Chronographia, ed. C. de Boor, Bd.1, Leipzig 1883 und 1885.

Theophanes Continuatus: Theophanes Continuatus, Ioannes Cameniata, Symeon magister, Georgius monachus, ed. I. BeKKer (CSHB 31), Bonn 1838.

Traumbuch des Achmet: Achmetis Oneirocriticon, ed. F. DreXL, Leipzig 1925.

Traumbuch des Patriarchen Germanos, ed. F. DreXL, Laogr. 7 (1923), 433-448.

Traumbuch des Propheten Daniel, ed. F. Drexl, BZ 26 (1926), 290-314.

Traumbuch des Pseudo-Nikephoros, Libro dei sogni, testo critico, introduzione, traduzione e commento a cura di G. GuIdorizzi (KOINSNIA 5), Neapel 1980.

Vita Danielis Stylitae: Les Saints Stylites, ed. H. Delehaye, Bruxelles 1923, (Neudruck 1989), 1-94.

Vita Nicolai Sionitae: Die Vita Nicolai Sionitae: griechischer Text. Übersetzt und kommentiert von H. BLum, Bonn 1997.

Vita Pachomii: Sancti Pachomii, Vitae Greacae, ed. Hagiographi Bollandiani ex recensione F. Halkin (Subs. hag. 19), Bruxelles 1932.

- Le Corpus athénien de saint Pachome, ed. F. Halkin, avec une traduction française par A.-J. Festugière, Genève 1982.

Vita Symeon Stylitae iun. und Vita Marthae: La vie ancienne de S. Syméon Stylite le jeune, t. I: Introduction et texte grec, Bruxelles; t. II: Traduction et Commentaire, Vie grecque de sainte Marthe, mère de S. Syméon, ed. P. VAn den Ven (Subs. hag. 32), Bruxelles 1962 und 1970.

Vita et miracula S. Theclae: Vie et miracles de Sainte Thècle. Texte grec, traduction et commentaire par D. DAGRon (Subs. hag. 62), Bruxelles 1978.

Vita Theodori Syceotae: Vie de Théodore de Sykéôn, t. I: Texte grec, t. II: Traduction, commentaire et appendice, ed. A.-J. Festugière (Subs. hag. 48), Bruxelles 1970. 


\section{Sekundärliteratur}

Abrahamse, D., Introduction, in: Alexander, The byzantine Apocalyptic Tradition, Berkeley u. a. 1985, 1-9.

Alexander, P. J., The Byzantine Apocalyptic Tradition. Edited with an introduction by D. de F. Abrahamse, Berkeley u.a. 1985.

Allen, P., R. Canning, L. Cross (Hg.), Prayer and Spirituality in the Early Church, 3 Bde., Everton Park 1998-2003.

Alt, K., Plotin, Stuttgart 2005.

Anderson, G., Sage, Saint and Sophist. Holy Men and their Associates in the Early Roman Empire, London u. a. 1994.

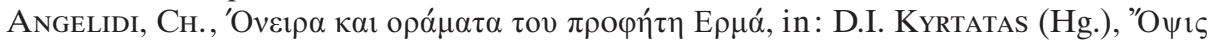

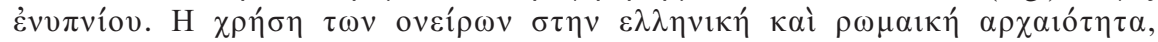
Herakleion 1993, 209-229.

Arbman, E., Ecstasy or Religious Trance. In the Experience of the Ecstatics and from Psychological Point of View, Bd. I: Vision and Ecstasy, Uppsala 1967; Bd. II: Essence and Forms of Ecstasy, Uppsala 1968; Bd. III: Ecstasy and Psychopathological States, Uppsala 1970.

Ariantzi, D., Kindheit in Byzanz. Emotionale, geistige und materielle Entwicklung im familiären Umfeld vom 6. bis zum 11. Jahrhundert, Berlin u. a. 2012.

BAcht, H., Art. Akoimeten, in: LThK 1, Freiburg i. Br. u. a. ${ }^{3} 1957$, Sp. 244-245.

- Ders., „Meditatio“, in den ältesten Mönchsquellen, in: Ders., Das Vermächtnis des Ursprungs I, Würzburg 1972, 244-264.

Baldwin, B., Art. Ephrem the Syrian, in: ODB 1, Oxford 1991, 708-709.

BARTELINK, G. J. M., Quelques observations sur ПАРPHऽIA dans la litterature paleochretienne, GLCP Suppl. 3 (1970), 7-57.

BAun, J., Tales from Another Byzantium. Celestical Journey and Local Community in the Medieval Greek Apocrypha, Cambridge 2007.

Baus K., E. Ewig, Die Reichskirche nach Konstantin dem Grossen. Erster Halbband: Die Kirche von Nikaia bis Chalkedon (HKG[J] 2), Freiburg i. Br. u.a. 1973.

Beatrice, P. F., Ascetical Fasting and Original Sin in the Early Christian Writers, in: Allen u.a., Prayer and Spirituality I (1998), 211-228.

Behr, C. A., Aelius Aristides and the Sacred Tales, Amsterdam 1968.

Benz, E., Die Vision. Erfahrungsformen und Bildwelt, Stuttgart 1969.

Berger, K., Formgeschichte des Neuen Testaments, Heidelberg 1984.

- Ders., Historische Psychologie des Neuen Testaments (Stuttgarter Bibel-Studien 146/147), Stuttgart 1991.

- Ders., Visionsberichte, Formgeschichtliche Bemerkungen über pagane hellenistische Texte und ihre frühchristlichen Analogien, in: Ders. (Hg.), Studien und Texte zur Formgeschichte, Tübingen 1992, 177-233.

- Ders., Darf man an Wunder Glauben?, Stuttgart 1996.

- Ders., Der Wundertäter. Die Wahrheit über Jesus, Freiburg i. Br. 2010.

Betz, O., Art. $\varphi \omega v \eta ́$, in: ThWNT 9, Stuttgart 1973, 272-302 (Unver. Nachdr. der 1933 erschien. Erstauflage).

Biedermann, H. M., Art. Mystik. A. Christentum. II. Ostkirchlicher Bereich, in: LexMa 6, München 1993, Sp. 989-991.

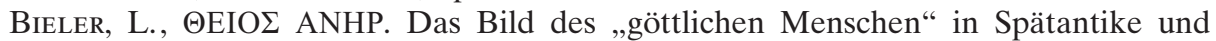
Frühchristentum. Darmstadt 1967 (Unver. Nachdr. der Ausgaben Wien 1935 und 1936). 
Binns, J., Ascetics and Ambassadors of Christ. The Monasteries of Palestine, 314-631, Oxford 1994.

BJÖRcK, G., ONAP I $\triangle$ EIN. De la perception de rêve chez les anciens, Er. 44 (1946), 306-314.

Blum, G. G., Byzantinische Mystik. Ihre Praxis und Theologie vom 7. Jahrhundert bis zum Beginn der Turkokratie, ihre Fortdauer in der Neuzeit, Berlin 2009.

Bolton, W. F., Parable, Allegorie and Romance in the Legend of Barlaam and Josaphat, Tr. 14 (1958), 359-66.

Bourguignon, E., Religion, Altered State of Consciousness, and Social change, Columbus 1973.

Bovon, F., These Christians Who Dream: The Authority of Dreams in the First Centuries of Christianity, in: Ders. (Hg.), Studies in Early Christianity, Tübingen 2003, 144-162.

Brakke, D., Demons and the Making of the Monk. Spiritual Combat in Early Christianity, Cambridge, Massachusetts u. a. 2006.

Braet, H., Rêve, réalité, écriture. Du référentiel à la sui-référence, in: T. Gregory (Hg.), I sogni nel medioevo, Seminario Internazionale Roma, 2-4 ottobre 1983 (Lessico Intellettuale Europeo 35), Rom 1985, 11-23.

Brandes, W., Apokalyptische Literatur, in: F. Winkelmann, W. Brandes (Hg.), Quellen zur Geschichte des frühen Byzanz (4.-9. Jahrhundert). Bestand und Probleme, Amsterdam 1990, 305-322.

- Ders., Anastasios ó díkopos. Endzeiterwartung und Kaiserkritik in Byzanz um 500 n. Chr., BZ 90 (1997), 24-63.

- Ders., Liudprand von Cremona (Legatio cap. 39-41) und eine bisher unbeachtete west-östliche Korrespondenz über die Bedeutung des Jahres 1000 a. D., BZ 93 (2000), 435-463.

- Ders., Endzeiterwartung im Jahre 1009 a.D.?, in: T. Pratsch (Hg.), Konflikt und Bewältigung. Die Zerstörung der Grabeskirche zu Jerusalem im Jahre 1009, Berlin u. a. 2011, 301-320.

Bravo García, A., La interpretación de los sueños en Bizancio, Erytheya 5 (1984), 63 82.

- Ders., Fisiología y filosofia en Aristóteles: el problema de los sueños, Cuadernos de Filología (Colegio Universitario de Ciudad Real) 4 (1985), 15-65.

- Ders., Sueño y ensueño en la literatura ascético-mística del siglo IV: Evagrio Póntico, in: M. Morfakidis (Hg.), La religion en el mundo griego: de la antigüedad a la Grecia moderna, Granada 1997, 183-193.

Brown, P., The Rise and Function of the Holy Man in Late Antiquity, JRS 61 (1971), 80-101.

- Ders., Society and the holy in late antiquity, New York 1982.

- Ders., Die Keuschheit der Engel. Sexuelle Entsagung, Askese und Körperlichkeit im frühen Christentum, München 1991 [Originaltitel: The body and society. Men, woman and sexual renunciation in early Christianity, New York 1988].

- Ders.: Die Gesellschaft und das Übernatürliche, Berlin 1993.

- Ders.: Autorität und Heiligkeit. Aspekte der Christianisierung des römischen Reiches, Stuttgart 1998 [Originaltitel: Authority and the Sacred. Aspects of the Christianisation of the Roman world, Cambridge u.a. 1995].

Brown Tkacz, C., Art. Prophet book, in: ODB 3, Oxford 1991, 1736-1737.

Browning, R., The ,Low Level' Saint's Life in the Early Byzantine World, in: S. Hackel (Hg.), The Byzantine Saint, University of Birmingham Fourteenth Spring 
Symposium of Byzantine Studies (Studies supplementary to Sobornost 5), London 1981, 117-127.

Calofonos, G., Dream Interpretation: A Byzantinist Superstition?, BMGS 9 (1984/ 85), 215-220.

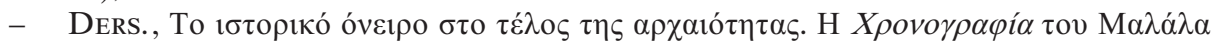

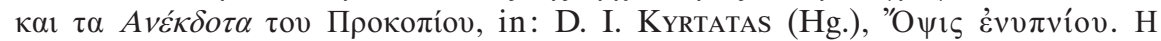

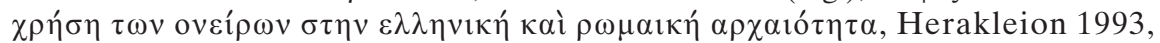
$283-322$.

Cameron, Al., Oracles and Earthquakes. A Note on the Theodosian Sibyl, in: C. Sode, S. A. TAKács (Hg.), Novum Millenium. Studies on Byzantine History and Culture Dedicated to Paul Speck, Aldershot 2001, 45-52.

Cameron, Av., Christianity and the Rhetoric of Empire. The Development of Christian Discourse (Sather Classical Lectures 55), Berkeley u.a. 1991.

- Dies., On defining the holy man, in: J. Howard-Johnston, P. A. Hayward (Hg.), The Cult of Saints in Late Antiquity and the Middle Ages. Essays on the Contribution of Peter Brown, Oxford 1999, 27-43.

Canivet, P., Le Monachisme syrien selon Théodoret de Cyr, Paris 1977.

Chadwick, H., Pachomios and the Idea of Sanctity, in: S. Hackel (Hg.), The Byzantine Saint, University of Birmingham Fourteenth Spring Symposium of Byzantine Studies (Studies supplementary to Sobornost 5), London 1981, 11-24.

Chitty, D. J., The Desert A City. An Introduction to the Study of Egyptian and Palestinian Monasticism under the Christian Empire, Oxford 1966.

Ciccarese, M. P., La genesi letteraria della visione dell'aldila: Gregorio Magno e le sue fonti, in: Sogni, Visioni e Profezie nell'antico cristianesimo, Roma, 5-7 Maggio 1987 (Aug. 29), Rom 1989, 435-449.

Clark, E. A., ,Spiritual Reading“: The Profit and Peril of Figurative Exegesis in Early Christian Asceticism, in: Allen u.a., Prayer and Spirituality I (1998), 251-274.

Colpe, C., Art. Himmelfahrt, in: RAC 15, Stuttgart 1991, 212-219.

- Ders., Archetyp und Prototyp. Zur Klärung des Verhältnisses zwischen Tiefenpsychologie und Geschichtswissenschaft, in: J. Assmann, (Hg.), Die Erfindung des inneren Menschen. Studien zur religiösen Anthropologie (Studien zum Verstehen fremder Religionen 6), Gütersloh 1993, 51-73.

- Ders., P. Habermehl, Art. Jenseitsreise, in: RAC 17, Stuttgart 1996, 490-543.

- Ders., E. Dassmann, J. Engemann, P. Habermehl, Art. Jenseitsfahrt I (Himmelfahrt), in: RAC 17, Stuttgart 1996, 407-466.

Consolino, F. E., Sogni e visioni nell' agiografia tardoantica: modelli e variazioni sul tema, in: Sogni, Visioni e Profezie nell'antico cristianesimo, Roma, 5-7 Maggio 1987 (Aug. 29), Rom 1989, 238-256.

Cox Miller, P., Dreams in Late Antiquity, Princeton 1994.

- Dies., The Poetry of Thought in Late Antiquity. Essays in Imagination and Religion, Aldershot u.a. 2001.

- Dies., The Corporeal Imagination. Signifying the Holy in Late Ancient Christianity, Philadelphia 2009.

Coyle, J. K, Early Monks, Prayer, and the Devil, in: Allen u. a., Prayer and Spirituality I (1998), 229-249.

- Ders., What Was „Prayer“ for Early Christians?, in: Allen u.a., Prayer and Spirituality II (1999), 25-41.

Csepregi, I., The miracles of saints Cosmas and Damian: characteristics of dream healing, Annual of Medieval Studies 8 (2002), 89-137. 
Cupane, C., Metamorphosen des Eros. Liebesdarstellung und Liebesdiskurs in der byzantinischen Literatur der Komnenenzeit, in: P. Agapitos, D. R. ReInsch (Hg.), Der Roman im Byzanz der Komnenenzeit, Referate des Internationalen Symposiums an der Freien Universität Berlin, 3. bis 6. April 1998 (Meletemata 8), Frankfurt 2000, 25-54.

Dagron, G., Idées byzantines, 2 Bde., Paris 2012.

- Ders., Quand la terre tremble ..., in: Ders., Idées byzantines I (2012), 3-22.

- Ders., L'hagiographie en question. Le saint, le savant, l'astrologue à travers les recueils de „Questions et réponses“ (Ve-VIIe s.) (Version remaniée de: Le saint, le savant, l'astrologue. Étude de thèmes hagiographiques à travers quelques recueils de Questions et Réponses des Ve-VIIe siècles, dans Hagiographie, cultures et Sociétés $\left[4^{\mathrm{e}}-12^{\mathrm{e}}\right.$ Siècles], Paris 1981, 143-156), in: Ders., Idées byzantines I (2012), 53-78.

- Ders., G., Le culte des images dans le monde byzantin, in: J. Delumeau (Hg.), Histoire vécue du peuple chrétien, Toulouse 1979, 133-160.

- Ders., Rêver de Dieu et parler de soi: le rêve et son interprétation d'après les sources byzantines, in: T. Gregory (Hg.), I sogni nel medioevo, Seminario Internazionale Roma, 2-4 ottobre 1983 (Lessico Intellettuale Europeo 35), Rom 1985, $37-55$.

DaniÉlou, J., Platonisme et théologie mystique: Doctrine spirituelle de Saint Grégoire de Nysse, Paris 1944.

Davis, S. T., The Cult of Saint Thecla: A Tradition of Women's Piety in Late Antiquity, Oxford 1995.

Dean-Otting, M., Heavenly Journeys. A Study of the Motif in Hellenistic Jewish Literature (JudUm 8), Frankfurt 1984.

Del Corno, D. (Hg.), Graecorum de re onirocritica scriptorum reliquiae, Mailand 1969.

- Ders., I sogni e la loro interpretazione dell' età dell' imperio, in: ANRW 16.2 (1978), 1605-1618.

- Ders., Dreams and their Interpretation in Ancient Greece, BICS 29 (1982), 55-62.

Delehaye, H., Les saints Stylites, Bruxelles 1923.

Delierneux, N., L'exploitation des topoi hagiographiques: du cliché figé à la réalité codée, Byz 70 (2000), 57-90.

Deubner, L., Kosmas und Damian. Texte und Einleitung, Leipzig u.a. 1907.

Dickie, M. W., Magic and Magicians in the Graeco-Roman World, London u. a. 2001.

Dihle, A., Art. Demut, in: RAC 3, Stuttgart 1957, 738-778.

Dinzelbacher, P., Die Jenseitsbrücke im Mittelalter, Wien 1973.

- Ders., Vision und Visionsliteratur im Mittelalter, Stuttgart 1981.

- Ders., Körperliche und seelische Vorbedingungen religiöser Träume und Visionen, in: T. Gregory, (Hg.), I sogni nel medioevo, Seminario Internazionale Roma, 2-4 ottobre 1983 (Lessico Intellettuale Europeo 35), Rom 1985, 57-86.

- Ders., Mittelalterliche Vision und moderne Sterbeforschung, in: J. KüHNEL, H.-D. Mück (Hg.) u.a., Psychologie in der Mediävistik, Gesammelte Beiträge des Steinheimer Symposions (1985), Göppingen 1985, 9-49.

- Ders., Mittelalterliche Visionsliteratur. Eine Anthologie, Darmstadt 1989.

- Ders., Revelationes (TSMÂO 57), Turnhout 1991.

- Ders., Nova visionaria et eschatologia, Mediaevistik 6 (1993), 45-84.

- Ders., Himmel, Hölle, Heilige. Visionen und Kunst im Mittelalter, Darmstadt 2002.

- Ders., Art. Mystik. A. Christentum. I. Westliches Mittelalter, in: LexMa 6, München 1993, Sp. 982-988. 
- Ders., Art., Visio(n), -sliteratur. A. I. Allgemein, in: LexMa 8, München 1997, Sp. $1734 \mathrm{f}$.

Dodds, E. R., The Greeks and the Irrational, Berkeley u.a. 1951.

- Ders., Pagan and Christian in an Age of Anxiety, Cambridge 1965.

Dodel, F., Das Sitzen der Wüstenväter: eine Untersuchung anhand der Apophthegmata Patrum (Paradosis 42), Freiburg 1997.

Dölger, F. J., Der Einfluß des Origenes auf die Beurteilung der Epilepsie und Mondsucht im christlichen Altertum, AuC 4 (1934), 95-109.

- Ders., Die Sonne der Gerechtigkeit und der Schwarze. Eine religionsgeschichtliche Studie zum Taufgelöbnis (Liturgische Forschungen 2), Münster 1918.

Draguet, M. R., Les Pères du Désert, Paris 1949.

Dronke, P., Imagination in the Late Pagan and Early Christian World. The First Nine Centuries A.D. (Millennio Medievale 42), Florenz 2003.

Duffy, J., Byzantine Medicine in the sixth and seventh centuries, DOP 38 (1984), 21 27.

Dummer, J., Zum Reflex des Bilderstreites in der byzantinischen Hagiographie, in: J. Irmscher, J., Der byzantinische Bilderstreit. Sozialökonomische Voraussetzungen, ideologische Grundlagen, geschichtliche Wirkungen, Leipzig 1980, 91-103.

- Ders., Griechische Hagiographie, in: F. Winkelmann, W. Brandes (Hg.), Quellen zur Geschichte des frühen Byzanz (4. -9. Jahrhundert). Bestand und Probleme, Amsterdam 1990, 284-296.

Edelstein, E. J., L., Asclepius, A Collection and Interpretation of the Testimonies, 2 Bde., Baltimore 1945.

Efthymiadis, S., V. Déroche, Greek Hagiography in Late Antiquity (Fourth-Seventh Centuries), in: Ders. (Hg.), The Ashgate Research Companion to Byzantine Hagiography, I: Periods and Places, Farnham u. a. 2011, 35-94.

- Ders., Hagiography from the 'Dark Age' to the Age of Symeon Metaphrastes (Eigth-Tenth Centuries), in: Ders. (Hg.), The Ashgate Research Companion to Byzantine Hagiography, I: Periods and Places, Farnham u. a. 2011, 95-142.

EhrLich, E. L., Der Traum im Alten Testament (BZAW 73), Berlin 1953.

Festugiere, A.-J., Lieux communs littéraires et thèmes de folk-lore dans l'Hagiographie primitive, WSt 73 (1960), 123-152.

- Ders., A.-J., Les moines d'Orient I-IV, Paris 1961.

Flusin, B., Miracle et histoire dans l'oeuvre de Cyrille de Scythopolis, Paris 1983.

FögEN, M. T., Die Enteignung der Wahrsager. Studien zum kaiserlichen Wissensmonopol in der Spätantike, Frankfurt 1993.

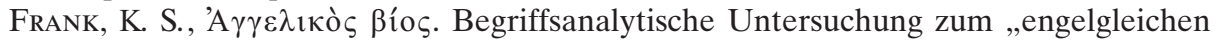
Leben“ im frühen Mönchtum (BGAM 26), Frankfurt 1964.

Frenschkowski, M., Traum und Traumdeutung im Matthäusevangelium, JAC 41 (1998), 5-47.

- Ders., C. Morgenthaler, Art. Traum, in: TRE 34, Berlin u.a. 2002, 28-50.

Gascou, J., Les origines du culte des saints Cyr et Jean, AnBoll 125 (2007), 241-284.

Gaston, R. W., Attention and Decorum in Early Christian Prayer, in: Allen u.a., Prayer and Spirituality I (1998), 81-96.

Gerok-Reiter, A., Einleitung: Zwischen den Welten, in: A. Gerok-Reiter, C. Walde (Hg.), Traum und Vision in der Vormoderne. Traditionen, Diskussionen, Perspektiven, Berlin 2012, 7-17.

Goodman, F. D., Trance. Der uralte Weg zum religiösen Erleben. Rituelle Körperhaltungen und ekstatische Erlebnisse, 1992. 
- Dies., Ekstase, Besessenheit, Dämonen. Die geheimnisvolle Seite der Religion. Gütersloh 1991 [Originaltitel: How about Demons? Bloomington 1988].

- Dies., Die andere Wirklichkeit: Über das Religiöse in den Kulturen der Welt, München 1994 [Originaltitel: Ecstasy, Ritual, and Alternate Reality. Religion in a Pluralistic World, Bloomington u.a. 1988].

Gould, G., The Desert Fathers on Monastic Community, Oxford 1993.

Grabar, A., Martyrium. Recherches sur le culte des reliques et l'art chrétien antique. Iconographie, Bd. II, Paris 1946.

Graf, F., Heiligtum und Ritual. Das Beispiel der griechisch-römischen Asklepieia, in: Le sanctuaire grec (EnAC 37), Genf-Vandoeuvres 1992, 159-199.

- Ders., Art. Ekstase, in: DNP, Stuttgart u. a. 1997, 950-952.

Guidorizzi, G., L'interpretazione dei sogni nel mondo tardoantico: oralità e scrittura, in: T. Gregory (Hg.), I sogni nel medioevo, Seminario Internazionale Roma, 2-4 ottobre 1983 (Lessico Intellettuale Europeo 35), Rom 1985, 149-170.

- Ders., La letteratura dell' irrazionale, in: G. Cambiano, D. Lanza (Hg.), Lo spazzio letterario della grecia Antica II, La ricezione e l'attualizzazione del testo, Rom 1995, 591-627.

Guillaumont, A., C. Guillaumont, Art. Démon: III. Dans la plus ancienne littérature monastique, in: Dictionnaire de spiritualité ascétique et mystique: Doctrine et histoire 3, Paris 1957, 189-212.

- Ders., Un philosophe au désert: Evagre le Pontique, RHR 181 (1972), 29-56.

- Ders., La vision de l'intellect par lui-même dans la mystique évagrienne, Melanges de l'Université Saint-Joseph L (vol. I-II), Beyrouth 1984, 255-262 (Nachdr. in: Études sur la spiritualité de l'Orient chrétien [Spiritualité Orientale 66], Abbaye de Bellefontaine 1996, 144-150).

Habermehl, P., Perpetua und der Ägypter oder Bilder des Bösen im frühen afrikanischen Christentum. Ein Versuch zur Passio Perpetuae et Felicitatis (TU 140), Berlin ${ }^{2} 1992$.

HäGG, T., The life of St. Antony between Biography and Hagiography, in: S. EFTHYMIADIS (Hg.), The Ashgate Research Companion to Byzantine Hagiography, I: Periods and Places, Farnham u. a. 2011, 18-34.

Hahn, I., Traumdeutung und gesellschaftliche Wirklichkeit: Artemidorus Daldiensis als sozialgeschichtliche Quelle (Xenia 27), Konstanz 1992.

Halfwassen, J., Plotin und der Neuplatonismus, München 2004.

Hammerstaedt, J., Geister im Zeugenstand. Die früheste lateinische Dämonologie in Tertullians Apologeticum, in: H.-J. HoRn (Hg.), Jakobs Traum. Zur Bedeutung der Zwischenwelt in der Tradition des Platonismus (Itinera Classica 1), St. Katherinen 2002, 25-41.

Hanson, J. S., Dreams and Visions in the Graeco-Roman World and Early Christianity, in: ANRW II 23.2 (1980), 1395-1427.

Harmless, W., Desert Christians: An Introduction to the Literature of Early Monasticism, Oxford u. a. 2004.

Hartmann, G., Selbstsigmatisierung und Charisma christlicher Heiliger der Spätantike, (Studien und Texte zu Antike und Christentum 38), Tübingen 2006.

Hausherr, I., Penthos. La doctrine de componction dans l'Orient Chrétien, (OrChrA 132), Rom 1944.

- Ders., L'Hésychasme. Étude de spiritualité, OCP 22 (1956), 5-40, 247-285.

Hehl, E.-D., Politische Träume und Visionen im Mittelalter, in: A. GeroK-Reiter, C. Walde (Hg.), Traum und Vision in der Vormoderne. Traditionen, Diskussionen, Perspektiven, Berlin 2012, 197-215. 
Heinemann, K., Die Ärzteheiligen Kosmas und Damian, Medizinhistorisches Journal 9 (1974), 255-317.

Hevelone-Harper, J., Disciples of the Desert: Monks, Laity, and Spiritual Authority in Sixth-Century Gaza, Baltimore 2005.

Hiestand, R. (Hg.), Traum und Träumen. Inhalt, Darstellung, Funktion einer Lebenserfahrung in Mittelalter und Renaissance (StH 24), Düsseldorf 1994.

Hinterberger, M., Autobiographische Traditionen in Byzanz (Wiener Byzantinistische Studien 22), Wien 1999.

Hoffman, K., Zur Aktualität der Besessenheit, in: Goodman, Ekstase (1997), 9-19.

Hoheisel, K., Art. Vision/Visionsbericht, in: RGG ${ }^{4}$ 8, Tübingen 2005, Sp. 1126 f.

Holl, K., Der Anteil der Styliten am Aufkommen der Bilderverehrung, in: Ders., Gesammelte Aufsätze zur Kirchengeschichte II, Der Osten, Tübingen 1928, 388 398.

Horn, J., Art. Esnē, in: LThK 3, Freiburg i. Br. u. a. ${ }^{3} 1995$, Sp. 883 f.

Hunger, H., Prooimion. Elemente der byzantinischen Kaiseridee in den Arengen der Urkunden (Wiener Byzantinische Studien 1), Wien 1964.

Irmscher, J., A. Kazhdan, A. Cutler, Art. Visions, in: ODB 3, Oxford 1991, 2179 f.

Ivanov, S. A., Holy Fools in Byzantium and Beyond, Oxford 2006.

Johanek, P., Die Wahrheit der mittelalterlichen Historiographen, in: F. P. Knapp, M. Niesner (Hg.), Historisches und fiktionales Erzählen im Mittelalter, Berlin 2002, $9-26$.

Johnson, S. F., The life and Miracles of Thekla, Cambridge Mass. u.a. 2006.

Kablitz, A., Art. Allegorische Interpretation, in: Metzler Lexikon Literatur- und Kulturtheorie, Stuttgart ${ }^{2} 2001,8-10$.

Kapelle, van De, R. P., Prophets and Mantics. A Response to E. R. Dodds, in: R. E. Smith, J. Lounibos (Hg.), Pagan and Christian Anxiety, Lanham u. a. 1984, 87-111.

Kazhdan, A., Art. Anargyroi, in: ODB 1, Oxford 1991, 85.

- Ders., A. Cutler, Art. Ecstasy, in: ODB 1, Oxford 1991, 675.

- Ders. u. a., Art. Dionysios the Aeropagite, Pseudo-, in: ODB 1, Oxford 1991, 629 f.

- Ders. u.a., Art. Gregory of Nyssa, in: ODB 2, Oxford 1991, 882.

- Ders., Holy and Unholy Miracle Workers, in: H. Maguire (Hg.), Byzantine Magic, Dumbarton Oaks 1995, 73-82.

- Ders., A History of Byzantine Literature (650-850), in Collaboration with L. F. Sherry, C. Angelidi, Athen 1999.

Kelsey, M. T., Trance, Ekstase und Dämonen, München 1994 [Originaltitel: How about Demons?, Bloomington 1988].

Klitenic Wear, S., u.a., Dionysius the Areopagite and the Neoplatonist Tradition, Aldershot 2007.

Kessels, A. H. M., Ancient Systems of Dream-classification, Mn. 22 (1969), 389-424.

- Ders., Studies on the Dream in Greek Literature, Utrecht 1978.

Kitzinger, E., The Cult of the Images in the Age before Iconoclasm, DOP 8 (1954), $83-150$.

Konstantinovsky, J., Evagrius Ponticus. The Making of a Gnostic, Farnham 2009.

Kreuzer, A., Art. Visio, in: Historisches Wörterbuch der Philosophie 11, Darmstadt 2001, Sp. $1068-1071$.

KRÖNUNG, B., Ekstasen und andere Formen von Visionserfahrungen in der frühbyzantinischen monastischen Literatur, in: A. Gerok-Reiter, C. Walde (Hg.), Traum und Vision in der Vormoderne. Traditionen, Diskussionen, Perspektiven, Berlin 2012, 65-90. 
Krovoza, A., Die Stellung Freuds zur Vorgeschichte der Traumdeutung. Nachwort, in: WALDE, Antike Traumdeutung und moderne Traumforschung (2001), 223-233.

Kunz, C. E., Schweigen und Geist. Biblische und patristische Studien zu einer Spiritualität des Schweigens, Freiburg i. Br. u. a. 1996.

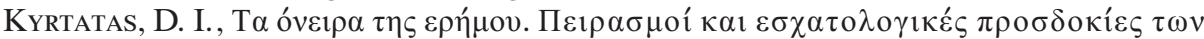

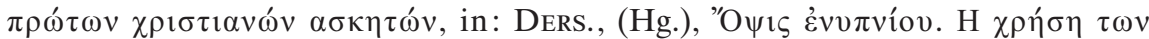

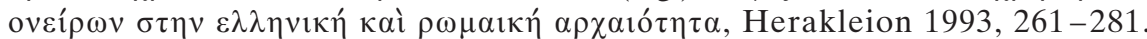

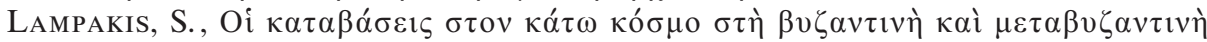

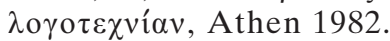

LANZONI, F., Il sogno presago della madre incinta nella letteratura medievale e antica, AnBoll 45 (1927), 225-261.

Latacz, J., Die Lesersteuerung durch Träume. Der Traum der Penelope im 19. Gesang der Odyssee, in: H. Froning u.a. (Hg.), Kotinos, Festschrift für E. Simon, Mainz 1992, 76-87.

Lauer, H., Art. Schlaf, in: LexMa 7, München 1995, Sp. 1470-1472.

Le Goff, J., Le christianisme et les rêves ( $\mathrm{II}^{\mathrm{e}}-\mathrm{VII}^{\mathrm{e}}$ siècles), in: T. Gregory, (Hg.), I sogni nel medioevo, Seminario Internazionale Roma, 2-4 ottobre 1983 (Lessico Intellettuale Europeo 35), Rom 1985, 171-218.

LewIS, I. M., Art. Ekstase, in: RGG ${ }^{4}$ 2, Tübingen 2005, Sp. 1186-1188.

Lesky, E., J. H. Waszink, Art. Epilepsie, in: RAC 5, Stuttgart 1962, 819-831.

LiEnHARD, B., Vom arabischen Buch Bilawhar wa- Būdāsf zum byzantinischen Barlaam und Ioasaph. Textumformungen am Beispiel der Sämannsparabel, in: G. CARbonaro, E. Creazzo (Hg.) u.a., Medioevo romanzo e orientale. Macrotesti fra Oriente e Occidente, IV Colloquio Internazionale, Vico Equense, 26-29 ottobre 2000, Soveria Mannelli 2003, 495-507.

Lifshitz, F., Beyond Positivism and Genre: „Hagiographical“ Texts as historical narrative, Viator 25 (1994), 96-113.

Lorenz, R., Das vierte Jahrhundert, Der Osten (KIG 1, Lfg C, 2), Göttingen 1992.

LuCK, G., Magie und andere Geheimlehren in der Antike (KTA 489), Stuttgart 1990.

LutzKa, C., Die Kleinen Horen des byzantinischen Stundengebetes und ihre geschichtliche Entwicklung, Berlin ${ }^{2} 2010$.

MacAlister, S., Dreams and Suicides. The Greek Novel from Antiquity to the Byzantine Empire. The Novel, the Dream and Suicide in the interim Period, New York 1996.

Magdalino, P., The History of the Future and its Uses: Prophecy, Policy and Propaganda, in: R. Beaton, C. Rouché (Hg.), The Making of Byzantine History. Studies Dedicated to Donald M. Nicol, Aldershot 1993, 3-43.

- Ders., Une prophétie inédite des environs de l'an 965 attribuée à Léon le Philosophe (Ms. Karakallou 14, f. 253 -254 ), TM 14 (2002), 391-402.

- Ders., The Year 1000 in Byzantium, in: P. Magdalino (Hg.), Byzantium in the Year 1000, Leiden-Boston 2003, 233-270.

- Ders., The End of Time in Byzantium, in: Brandes u.a. (Hg.), Endzeiten. Eschatologie in den monotheistischen Weltreligionen, Berlin u.a. 2008, 119-133.

Maguire, H., A. Kazhdan, Byzantine Hagiographical Texts as Sources on Art, DOP 45 (1991), 1-22.

- Ders., Magic and the Christian Image, in: Ders. (Hg.), Byzantine Magic, Dumbarton Oaks 1995, 51-71.

Mainberger, G. K., Art. Imagination, in: PZJ 15, Zürich 1979, 25 -43.

MaKris, G., Zur Epilepsie in Byzanz, BZ 88 (1995), 363-404. 
Maltese, E. V., Il Libro di Sindbad. Novelle persiane medievali dalla versione bizantina di Michele Andreopoulos, Turin 1993.

- Ders., Dimensione bizantine. Donne angeli e demoni nel Medioevo greco, Turin 1995, 49-92. 139-156.

Manuwald, B., Traum und Traumdeutung in der griechischen Antike, in: R. Hiestand (Hg.), Traum und Träumen. Inhalt, Darstellung, Funktion einer Lebenserfahrung in Mittelalter und Renaissance (StH 24), Düsseldorf 1994, 15-42.

Mavroudi, M., A Byzantine Book on Dream Interpretation. The Oneirocriticon of Achmet and Its Arabic Sources (The Medieval Mediterranean 36), Leiden u.a. 2002.

McGuckin, J. A., The Prayer of the Heart in Patristic and Early Byzantine Tradition, in: Prayer and Spirituality II (1999), 69-108.

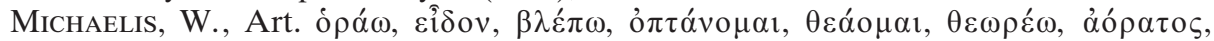

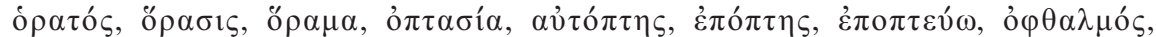

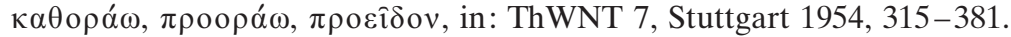

Michl, J., Art. Engel IV (christliche), in: RAC 5, Stuttgart 1962, 109-200.

Müller, A., Die Vita des Sinaiten von Daniel von Raithu. Ein Beitrag zur byzantinischen Hagiographie, BZ 95/2 (2002), 585-601.

Müller, B., Der Weg des Weinens. Die Tradition des „Penthos“ in den Apophthegmata Patrum (FKDG 77), Göttingen 2000.

Müller, C. D. G., Von Teufel, Mittagsdämon und Amuletten, JAC 17 (1974), 91-102.

Mullet, M., Dancing with Deconstructionists in the Gardens of the Muses: New Literary History vs?, Byzantine and Modern Greek Studies 14 (1990), 258-275.

- Dies., The Madness of Genre, DOP 46 (1992), 233-243.

NäF, B., Traum und Traumdeutung im Altertum, Darmstadt 2004.

Oberhelman, S. M., The Oneirocriticon of Achmet. A Medieval Greek and Arabic Treatise on the Interpretation of Dreams, Texas 1991.

- Ders., Dreambooks in Byzantium. Six Oneirocritica in translation, with commentary and introduction, Aldershot 2008.

Overwien, O., Neues zu den Quellen der Vita Antonii des Athanasius, Millenium 3 (2006), 159-184.

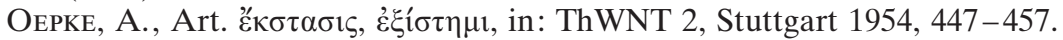

- Ders., Art. ővap, in: ThWNT 7, Stuttgart 1954, 220-238.

Patlagean, É, Sainteté et pouvoir, in: S. Hackel (Hg.), The Byzantine Saint, University of Birmingham Fourteenth Spring Symposium of Byzantine Studies (Studies supplementary to Sobornost 5), London 1981, 88-105.

PeIL, D., Art. Allegorie, in: Metzler Lexikon Literatur- und Kulturtheorie, Stuttgart ${ }^{2} 2001,8$.

Pfister, F., Art. Ekstase, RAC 4, Stuttgart 1959, $944-987$.

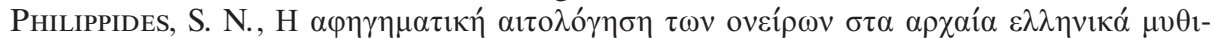

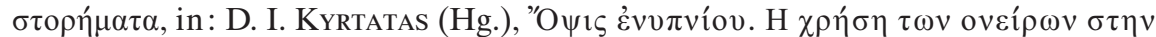

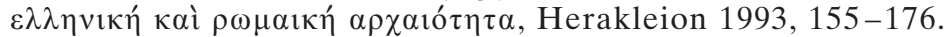

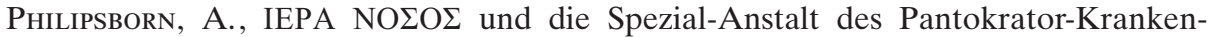
hauses, Byz 33 (1963), 223-230.

Podkalsky, G., Byzantinische Reichseschatologie. Die Periodisierung der Weltgeschichte in den vier Grossreichen (Daniel 2 und 7) und dem tausendjährigen Friedensreiche (Apok. 20). Eine Motivgeschichtliche Untersuchung, München 1972. 
Pratsch, T., Exploring the Jungle - Hagiographical Literature between Fact and Fiction, in: A. Cameron (Hg.), Fifty Years of Prosopography (Proceedings of the British Academy 118), London 2003, 59-72.

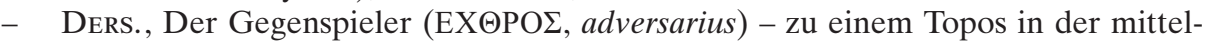
byzantinischen Heiligenliteratur, ABzF N. S. (2003-2004), 72-89.

- Ders., Der hagiographische Topos. Griechische Heiligenviten in mittelbyzantinischer Zeit, Berlin u. a. 2005.

- Ders., „... erwachte und war geheilt“ - Inkubationsdarstellungen in byzantinischen Heiligenviten, ZAC (im Druck).

RAPP C., „For next to God, you are my salvation“. Reflections on the Rise of the Holy Man in Late Antiquity, in: J. Howard-Johnston, P. A. Hayward (Hg.), The Cult of Saints in Late Antiquity and the Middle Ages. Essays on the Contribution of Peter Brown, Oxford 1999, 63-81.

- Dies., Holy Bishops in Late Antiquity: The Nature of Christian Leadership in an Age of Transition, Berkeley u.a. 2005.

- Dies., The Origins of hagiography and the literature of early monasticism: purpose and genre between tradition and innovation, in: Ch. Kelly, R. Flower, M. S. Williams (Hg.), Unclassical Traditions. Volume I: Alternatives to the classical past in Late Antiquity, Cambridge 2010, 119-130.

Refoulé, F., Rêves et vie spirituelle d'après Evagre le Pontique, in: Supplément de la vie spirituelle 59 (1961), 470-516.

Reinsch, D. R., Autor und Leser in frühbyzantinischen hagiographischen Texten und historiographischen Werken, in: 18. International Congress of Byzantine Studies. Major Papers, Moskau 1991, 400-414.

Rousseau, P., Pachomius. The Making of a Community in Fourth-Century Egypt, Berkeley u.a. 1985.

- Ders., Ascetics as mediators and as teachers, in: J. Howard-Johnston, P. A. Hayward (Hg.), The Cult of Saints in Late Antiquity and the Middle Ages. Essays on the Contribution of Peter Brown, Oxford 1999, 45-62.

Rubenson, R., Anthony and Pythagoras: A Reappraisal of the Appropriation of Classical Biography in Athanasius' Vita Antonii, in: D. Brakke, A.-C. Jacobsen, J. Ulrich (Hg.), Beyond Reception - Mutual Influences between Antique Religion, Judaism, and Early Christianity, Frankfurt 2006, 191-208.

- Ders., The Transformation of the Ascetic in Early Egyptian Monasticism, in: T. K. Seim, J. ØKland (Hg.), Metamorphoses. Resurrection, Body and Transformative Practices in Early Christianity (Ekstasis. Religious Experience from Antiquity to the Middle Ages 1), Berlin u. a. 2009, 271-289.

Scarborough, J., Art. Insanity, in: ODB 2, Oxford 1991, 998.

Scharfetter, C., Allgemeine Psychopathologie. Eine Einführung, Stuttgart u. a. ${ }^{5} 2002$.

Schiffer, E., Art. Hagiographie, in: Historisches Wörterbuch der Rhetorik 3, Tübingen 1996, 1277-1280.

- DiEs., Zur Bewertung des Schweigens in byzantinisch-monastischer Tradition, JÖB 52 (2002), 1-22.

Schimmel, A., Art. Ekstase, in: RGG 2, Tübingen 1958, 410-412.

- Dies., Mystische Dimensionen des Islam: Die Geschichte des Sufismus, Köln ${ }^{2} 1992$.

- Dies., Sufismus. Eine Einführung in die islamische Mystik, München 2000.

Schröder, H. O., Publius Aelius Aristides. Heilige Berichte. Einleitung, deutsche Übersetzung und Kommentar, Heidelberg 1986. 
Schulz, G., J. ZIEMER, Mit Wüstenvätern und Wüstenmüttern im Gespräch, Göttingen 2010.

Seprälä, S., In speechless Ecstasy. Expression and Interpretation of Mystical Experience in Classical Syriac and Sufi Literature, Helsinki 2003.

Ševčenko, I., Hagiography of the Iconoclast Period, in: A. Bryer, Herrin J. (Hg.), Iconoclasm, Birmingham 1977, 113-131.

Severus, E., Art. Gebet I, RAC 8, Stuttgart 1972, 1134-1258.

SöDER, Rosa, Die apokryphen Apostelgeschichten und die romanhafte Literatur der Antike, Stuttgart 1932.

SPECK, P., Weitere Überlegungen und Untersuchungen über die Ursprünge der byzantinischen Renaissance, in: Varia II (ПOIKI^A BYZANTINA 6), Bonn 1987, $255-283$.

- Ders., Byzantium: cultural suicide?, in: L. Brubacker (Hg.), Byzantium in the ninth century: dead or alive?, Papers from the Thirtieth Spring Symposium of Byzantine Studies, Birmingham, March 1996 (Society for the Promotion of Byzantine Studies 5), Aldershot u. a. 1998, 74-84.

SpeYer, W., Zum Bild des Apollonios von Tyana bei Heiden und Christen, JAC 17 (1974), 47-63.

- Ders., Der christliche Heilige der Spätantike. Wesen, Bedeutung, Leitbild, in: J. Dummer, M. Vielberg (Hg.), Leitbilder in der Diskussion (Altertumswissenschaftliches Kolloquium 3), Stuttgart 2001, 79-92.

Stathakopoulos, D., Rain Miracles in Late Antiquity. An Essay in Typology, JÖB 52 (2002), 73-87.

Stichel, R., Studien zum Verhältnis von Text und Bild spät- und nachbyzantinischer Vergänglichkeitsdarstellungen (Byzantina Vindobonensia 5), Wien u.a. 1971.

van Straten, F. T., Diakrates' Dream. A Votive Relief from Kos, and Some Other kat' onar Dedications, BaBesch 15 (1976), 1-38.

Strathmann, H., P. Keseling, Art. Askese II (christlich), in: RAC 1, Stuttgart 1950, $749-795$.

Strobl, P., Die Macht des Schlafes in der griechisch-römischen Welt (Studien zur Geschichtsforschung des Altertums 11), Hamburg 2002.

TAFT, R. F., Art. Vigil ( $\pi \alpha v v v \chi i ́ \varsigma, \pi \alpha \rho \alpha \mu o v \eta ́, ~ \alpha ُ \gamma \rho v \pi v i ́ \alpha)$, in: ODB 3, Oxford 1991, 2166.

Talbot, A.-M., R. F. Taft, Art. Akoimetoi, Monastery of, in: ODB 1, Oxford 1991, 46.

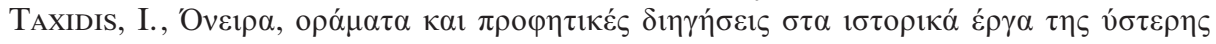

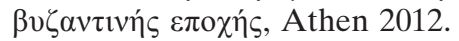

Temkin, O., The falling sickness. A history of epilepsy from the Greeks to the beginnings of modern neurology, Baltimore ${ }^{2} 1994$.

Timotin, A., Visions, prophéties et pouvoir à Byzance. Étude sur l'hagiographie mésobyzantine (IX-XI siècles), Paris 2010.

TworuschKa, U., Sucher, Pilger, Himmelsstürmer. Reisen im Diesseits und Jenseits, Stuttgart 1991.

Uthemann, K.-H., Art. Mysticism, in: ODB 2, Oxford 1991, 1431.

Van Uytfanghe, M., Art., Heiligenverehrung II (Hagiographie), in: RAC 14 Stuttgart 1988, 150-183.

- Ders., Art. Biographie II (spirituelle). C Christlich, in: RAC Supplement I, Stuttgart 2001, 1153-1336.

- Ders., La biographie classique et hagiographie chrétienne, Hagiographica 12 (2005), 223-248.

Vinagre, M. A., Die griechische Terminologie der Traumdeutung, Mn. 49 (1996), 257 282. 
Vincent-Bernardi, A.-M., La didascalie onirique. Ambivalence du rêve, dans l'Antiquité tardive et l'empire byzantin, in: G. Filoramo ( $\mathrm{Hg}$.), Maestro e discepolo. Temi e problemi della direzione spirituale tra VI secolo a.C. e VII secolo d.C., Brescia 2002, 127-139.

VIRT, G., Art. Wachsamkeit, in: LThK 10, Freiburg i. Br. u. a. ${ }^{3} 1965$, Sp. 916.

Volk, R., Die Schriften des Johannes von Damaskos, Bd. VI/1: Historia animae utilis de Barlaam et Joasaph (spuria). Einführung, Berlin u.a. 2009.

VölKer, W., Kontemplation und Ekstase bei Pseudo-Dionysius Areopagita, Wiesbaden 1958.

Vollmann, K., Erlaubte Fiktionalität: Die Heiligenlegende, in: F. P. KnapP, M. Niesner (Hg.), Historisches und fiktionales Erzählen im Mittelalter, Berlin 2002, $63-72$.

Vööвus, A., History of Asceticism in the Syrian Orient. A contribution to the History of Culture in the near East. I. The Origin of Ascetism. Early Monasticism in Persia, II. Early Monasticism in Mesopotamia and Syria, III. A Contribution to the History of Culture In the Near East, Louvain 1958-1988.

WaChT, M., Art. Inkubation, in: RAC 18, Stuttgart 1998, 179-265.

Walde, C., Art. Traum, in: Metzler Lexikon Religion, Stuttgart u. a. 2000, 530-532.

- Dies., Die Traumdarstellungen in der griechisch- römischen Dichtung. München u. a. 2001.

- Dies., Antike Traumdeutung und moderne Traumforschung, Zürich 2001.

- Dies., Traum und Traumdeutung in der griechisch-römischen Antike oder vom Zwang, Träume zu deuten, in: A. GeroK-Reiter, C. Walde (Hg.), Traum und Vision in der Vormoderne. Traditionen, Diskussionen, Perspektiven, Berlin 2012, $65-$ 90.

Weber, G., Herrscher und Traum in hellenistischer Zeit, Archiv für Kulturgeschichte 81 (1999), 1-33.

- Ders., Kaiser, Träume und Visionen in Prinzipat und Spätantike (Historia, Einzelschriften 243), Stuttgart 2000.

- Ders., Träume in der römischen Kaiserzeit. Normalität, Exzeptionalität und Signifikanz, in: K. Brodersen (Hg.), Gebet und Fluch, Zeichen und Traum. Aspekte religiöser Kommunikation in der Antike (Antike Kultur und Geschichte 1), Münster 2001, 89-109.

Weinstock, F., De somniorum visionumque in amatoriis graecorum fabulis vi atque usu, Eos 35 (1934), 29-72.

Welte, F. M., Art. Trance (-techniken), in: Metzler Lexikon Religion 3, Stuttgart u.a., 2000, 521-525.

Wikenhauser, A., Doppelträume, Bib. 29 (1948), 100-111.

Wissmann, H., Art. Ekstase, in: TRE 9, Berlin u.a. 1982, 488-491.

WitTmer- Butsch, M. E., Zur Bedeutung von Schlaf und Traum im Mittelalter (Medium aevum quotidianum 1), Krems 1990.

WöHrle, G., Hypnos, der Allbezwinger (Palingenesia 53), Stuttgart 1995.

Zeller, D., Geburtsankündigung und Geburtsverkündigung. Formgeschichtliche Untersuchung im Blick auf Mt $1 \mathrm{f}, \mathrm{Lk} 1 \mathrm{f}$., in: K. Berger (Hg.), Studien und Texte zur Formgeschichte, Tübingen 1992, 59-134.

ZGoll, A., Die Welt im Schlaf sehen - Inkubation von Träumen im antiken Mesopotamien, WO 32 (2002), 74-101. 